\title{
Characteristic of C1-C5 Carbonyls Removal by Indoor Plants under the Laboratory Condition of Different Light Intensities
}

\author{
Chunjuan Xie ${ }^{1}$, Jian $\mathrm{Li}^{2 *}$, Liushui Yan², Jiaochan Zhong ${ }^{2}$ \\ ${ }^{1}$ School of Science, East China Jiaotong University, Nanchang, China, 330013 \\ 2 Key Laboratory of Jiangxi Province for Persistant Pollutants Control and Resources Recycle, \\ School of Environmental and Chemical Engineering, Nanchang Hangkong University, Nanchang, \\ China, 330063 \\ *Email: lijian@nchu.edu.cn
}

\begin{abstract}
Keywords: Carbonyl compounds, Indoor plants, Light intensities,Low- Molecular weight
Abstract. Two indoor plants (Schefflera octophylla and Chamaedorea elegans) were selected for testing the removal characteristics of five carbonyl at the laboratory simulation environment of short-term exposure to different low light intensities. The results showed that under normal circumstances the $\mathrm{C}_{1}-\mathrm{C}_{5}$ aldehyde removal rates of Schefflera octophylla and Chamaedorea elegans were ranged from $0.311 \mu \mathrm{mol} / \mathrm{m}^{2} / \mathrm{s}$ for valeraldehyde to $0.677 \mu \mathrm{mol} / \mathrm{m}^{2} / \mathrm{s}$ for formaldehyde, and $0.526 \mu \mathrm{mol} / \mathrm{m}^{2} / \mathrm{s}$ for propionaldehyde to $1.440 \mu \mathrm{mol} / \mathrm{m}^{2} / \mathrm{s}$ for formaldehyde, respectively. However, when the light intensities varied from 0 to $80 \mu \mathrm{mol} / \mathrm{m}^{2} / \mathrm{s}$, a significant correlation between the aldehydes removal rate and the light intensity was found with the removal efficiency of above plant species ranged from 1.018 to 3.519 and ranged from 0.765 to $4.909 \mu \mathrm{mol} / \mathrm{m}^{2} / \mathrm{s}$ for the total carbonyls $\left(\mathrm{C}_{1}-\mathrm{C}_{5}\right.$ aldehydes), respectively. Consequently, different light intensities may have a positive effect on the removal of indoor gaseous carbonyls pollutants by indoor plants, and to maximize the improvement of indoor air quality, screening plant species with higher removal efficiency on VOCs were needed.
\end{abstract}

\section{Introduction}

The sources of ambient carbonyls have fuel combustion, vehicle exhaust, industrial exhaust gas and photochemical reaction, and they are also released from the indoor sources, such as incense burning, cigrette smoke and cooking exhausts [1]. It is unoptimistic to know that more than 300 volatile organic compounds (VOCs) having been detected as indoor air contaminants [2], and the adverse effect of indoor air pollution have become an issue of international concern due to most people spend large fractions (more than $80 \%$ ) of their time in indoor environments [3]. Weng et al. (2010) reported that the mean concentration of low molecular weight aldehydes $\left(\mathrm{C}_{1}-\mathrm{C}_{5}\right)$ were even more than $200 \mu \mathrm{g} \mathrm{m}-3$ in indoor residential air of Hangzhou, China in summer[4]. Low molecular weight aldehydes $\left(\leq \mathrm{C}_{5}\right)$ are an important class of volatile organic compounds in the atmospherc not only because some being classified as known or probable human carcinogens (e.g. Formaldehyde and acetaldehyde), but also for being dominant components among the total carbonyls in atmosphere of the most big cities in the world (Table 1) . 
Table 1 Comparison of Low molecular aldehydes with total carbonyls in the atmosphere at different cities

\begin{tabular}{|c|c|c|c|}
\hline Sample site & Sample period & $\begin{array}{l}\left(\mathrm{C}_{1}-\mathrm{C}_{5}\right. \\
\text { aldehydes }) / \text { (total } \\
\text { carbonyls in } \\
\text { respective } \\
\text { measure) }\end{array}$ & Referenc \\
\hline Beijing, China & August 2006 & $45.3-75.7 \%$ & {$[5]$} \\
\hline Shanghai, China & June 2008 & $47.7-53.8 \%$ & [6] \\
\hline $\begin{array}{l}\text { Guangzhou, } \\
\text { China }\end{array}$ & August-September 2002 & $60.3 \%$ & [7] \\
\hline $\begin{array}{l}\text { Guangzhou, } \\
\text { China }\end{array}$ & January-November 2005 & $41.1-62.0 \%$ & {$[8]$} \\
\hline $\begin{array}{l}\text { Hongkong, } \\
\text { China }\end{array}$ & $\begin{array}{l}\text { October1997-September } \\
2000\end{array}$ & $62.5-71.4 \%$ & [9] \\
\hline $\begin{array}{l}\text { Kaohsiung, } \\
\text { Taiwan }\end{array}$ & January- December 2006 & $64.3-66.3 \%$ & {$[10]$} \\
\hline Xi' an, China & June 2009, January 2010 & $65.9-71.9 \%$ & {$[11]$} \\
\hline Athens, Greece & June-December 2000 & $61.3-67.3 \%$ & [12] \\
\hline $\begin{array}{l}\text { Rio De Janeiro, } \\
\text { Brazil }\end{array}$ & May -November 2000 & $57.6-77.3 \%$ & {$[13]$} \\
\hline
\end{tabular}

$\mathrm{C}_{1}-\mathrm{C}_{5}$ aldehydes: formaldehyde, acetaldehyde, propionaldehyde, butyraldehyde, valeraldehyde.

In order to improves indoor air quality, many scholars try to use houseplants to absorb the indoor air pollutants. Previous studies have reported that plant can absorb inorganic pollutants such as $\mathrm{SO}_{2}$, $\mathrm{CO}, \mathrm{O}_{3}$ and $\mathrm{NOx}$ [14]. Plants can eliminate gaseous pollutants by the absorption through the stomata, and adsorption on the cuticle or epidermis of the leaf. Although previous studies on aldehydes absorption regarded that aldehydes absorption occurs via the stomata, but there is not direct evidence to get rid of the contribution of the cuticle. The stomata and the cuticle are the main uptake pathway for foliar plants to scavenge gaseous pollutants.

Light can induces plant stomatal movement. And pollutant removal by plant stomatal pathway may be effected as a result of light changes. It is known that formaldehyde and acetaldehyde can be taken up through stomata by plants and then participate in metabolism of plants [15], but how to be metabolized inside the leaf and be effected by light intensities are still unknown especially for the other aldehydes(e.g. $\mathrm{C}_{3}-\mathrm{C}_{5}$ aldehydes). The overall aim of this paper is to investigate the removal efficiencies of low molecular weight aldehydes $\left(\leq \mathrm{C}_{5}\right)$ by two houseplant species at the different indoor low light intensities and $\mathrm{CO}_{2}$ concentrations, and to try to discuss the absorption mechanism.

\section{Materials and Methods}

Aldehydes included formaldehyde (37\% in water), acetaldehyde (99.5\%), propionaldehyde (99.3\%), n-butyealdehyde (99.5\%), valeraldehyde $(99.3 \%)$ were purchased from Chemservice Corporation (West Chester, PA). Hexane (Absolv grade) was from TEDIA Corporation, USA. Pentafluorophenyl hydrazine (PFPH, 97\%, acting as an derivating agent) and 4-fluorobenzaldehyde (98\%, acting as an internal standard) were from Sigma-Aldrich, Germany. Tenax TA (60/80 mesh) was from CNW Technologies GmbH, Germany.

Two houseplant species were selected, including Schefflera octophylla and Chamaedorea elegans in pots(the pot diameter is about $16 \mathrm{~cm}$, and the houseplant is about $30 \mathrm{~cm}$ height ). These species were selected for their widespread use in indoor environment in Chinese homes. They were kept in their initial pots and potting soil, just as they were purchased from the market. Carbonyls were separated by GC (Agilent $7890 \mathrm{~N}$, USA) equipped with an HP-5MSI column (5\% phenyl Methyl Siloxane, $30 \mathrm{~m} \times 250 \mu \mathrm{m} \times 0.25 \mu \mathrm{m}$ film thickness). The inlet temperature of column was set at 
$275^{\circ} \mathrm{C}$. The column temperature was maintained at $72^{\circ} \mathrm{C}$ for $1 \mathrm{~min}$ after sample injection, then programmed to $110^{\circ} \mathrm{C}$ at a rate of $8^{\circ} \mathrm{C}$ min- 1 , and then to $200^{\circ} \mathrm{C}$ at $5.5^{\circ} \mathrm{C}$ min- 1 , kept at $200^{\circ} \mathrm{C}$ for 2 min, and finally heated to $300^{\circ} \mathrm{C}$. The $\mathrm{GC}$ chromatogram and the mass spectrum of the PFPHhydrazone derivatives for a standard mixture of the C1-C5 aldehydes are shown in Fig. 2 and Fig. 3. The MSD (5975MSD, USA) was regulared in electron ionization (EI) mode at $70 \mathrm{eV}$ and initially operated in scan mode to identify the most abundant ions and the molecular ion for each compound. The mass spectrometer was initially operated in scan mode with a mass range of 50 to 400 to identify the most abundant ions and the molecular ion of each compound. These characteristic ions were then used to identify and quantify the carbonyl compounds present in filed samples in selective ion monitoring (SIM) mode. The peak areas of both E- and Z-isomers of each carbonyl-PFPH derivative were utilized for the quantitative analysis (Li et al., 2009).

\section{Results and Discussion}

Plant emission experiments were conducted before removal experiments performed, and no emissions of the objective aldehydes from the selected houseplants were observed. Table 2 showed the removal rate of low-molecular mass aldehydes $\left(\mathrm{C}_{1}-\mathrm{C}_{5}\right)$ by the two houseplant species (Schefflera octophylla and Chamaedorea elegans) under a normal indoor environment (light intensity of about $40 \mu \mathrm{mol} \mathrm{m}-2 \mathrm{~s}-1$ ). The removal rates by Schefflera octophylla and Chamaedorea elegans were ranged from $0.311 \mu \mathrm{mol} \mathrm{m}-2 \mathrm{~h}-1$ for valeraldehyde to $0.677 \mu \mathrm{mol} \mathrm{m}-2 \mathrm{~h}-1$ for formaldehyde, and $0.526 \mu \mathrm{mol} \mathrm{m}-2 \mathrm{~h}-1$ for propionaldehyde to $1.440 \mu \mathrm{mol} \mathrm{m}-2 \mathrm{~h}-1$ for formaldehyde, respectively. The tested two plants exhibited a higher ability on formaldehyde removal than other aldehydes, and their removal rates of the lower aldehydes (formaldehyde and acetaldehyde) were higher than other aldehydes (C3-C5) for all plants in experiments.

Table 2 Removel rate for respective aldehyde by two houseplant species under a normal indoor environment.

\begin{tabular}{lll}
\hline Carbonyl compounds & \multicolumn{2}{l}{ Removal rate $\left(\mu \mathrm{mol} \mathrm{m} \mathrm{m}^{-2} \mathrm{~h}^{-1}\right)$} \\
\cline { 2 - 3 } & Schefflera octophylla & Chamaedorea elegans \\
\hline formaldehyde & $0.677 \pm 0.105$ & $1.440 \pm 0.270$ \\
acetaldehyde & $0.608 \pm 0.074$ & $0.995 \pm 0.131$ \\
propionaldehyde & $0.474 \pm 0.053$ & $0.698 \pm 0.091$ \\
n-butyraldehyde & $0.350 \pm 0.063$ & $0.544 \pm 0.041$ \\
n-valeraldehyde & $0.311 \pm 0.100$ & $0.526 \pm 0.143$ \\
Total & $2.420 \pm 0.395$ & $4.203 \pm 0.676$ \\
\hline
\end{tabular}

${ }^{a}$ Mean value and standard deviation $(\mathrm{n}=3)$

Light intensity: approximately $15 \mu \mathrm{mol} \mathrm{m} \mathrm{m}^{-2} \mathrm{~s}^{-1}$

The samplings under different light intensities $(\sim 80 \mu \mathrm{mol} \mathrm{m}-2 \mathrm{~s}-1)$ were performed both in the day and the night time (07:30 to 22:00). Fig 1 presented the removal rates of C1-C5 aldehydes under the three light intensities of $0,40,80 \mu \mathrm{mol} \mathrm{m}-2 \mathrm{~s}-1$. It was easy to see from Fig. 4 that all the aldehyde removal ratios raised with the increase of light intensity $(\sim 80 \mu \mathrm{mol} \mathrm{m}-2 \mathrm{~s}-1)$ and formaldehyde and acetaldehyde removal rates were obviously higher than other aldehydes (C3-C5) when the light intensity was raised from 0 to $80 \mu \mathrm{mol} \mathrm{m}-2 \mathrm{~s}-1$. The formaldehyde removal efficiency was highest among these aldehydes, and its removal rates were ranges from 0.211 to $1.933 \mu \mathrm{mol} \mathrm{m}-2 \mathrm{~h}-1$ for Chamaedorea elegans and from 0.073 to $1.296 \mu \mathrm{mol} \mathrm{m}-2 \mathrm{~h}-1$ for Schefflera octophylla., respectively. While n-butyraldehyde and valeraldehyde exhibited lower removal ratios (with a maximum value of 0.564 and $0.549 \mu \mathrm{molm}-2 \mathrm{~h}-1)$ compared with other three aldehydes (C1-C3). 


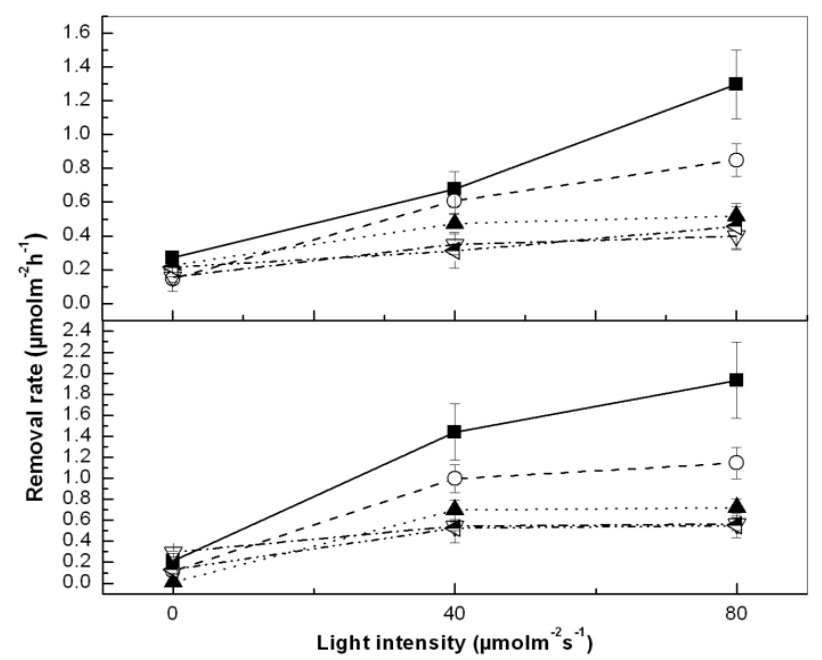

Fig. 1. Removal rate of $\mathrm{C}_{1}-\mathrm{C}_{5}$ aldehydes by Schefflera octophylla (a) and Chamaedorea elegans (b) at three light intensities $\left(0,40\right.$ and $\left.80 \mu \mathrm{mol} \mathrm{m}^{-2} \mathrm{~h}^{-1}\right)$. - Formaldehyde; - - - - - Acetaldehyde;

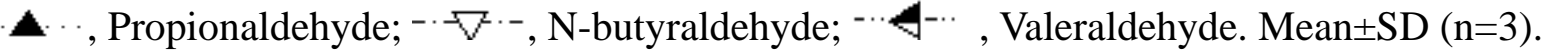

Significant differences for $\mathrm{p}<0.05$ are shown with least significant(LSD) test.

\section{Conclusions}

Two houseplant species (Schefflera octophylla and Chamaedorea elegans) were selected for testing the removal ratios of low-molecular mass aldehydes at the different light intensities in this study. At the normal environment with a light intensity of $40 \mu \mathrm{mol} \mathrm{m}-2 \mathrm{~s}-1$, the removal ratios of Schefflera octophylla and Chamaedorea elegans were ranged from $0.311 \mu \mathrm{mol} \mathrm{m}-2 \mathrm{~h}-1$ for valeraldehyde to $0.677 \mu \mathrm{mol} \mathrm{m}-2 \mathrm{~s}-1$ for formaldehyde, and $0.526 \mu \mathrm{mol} \mathrm{m}-2 \mathrm{~h}-1$ for propionaldehyde to $1.440 \mu \mathrm{mol}$ m-2 h-1 for formaldehyde, respectively. At the light intensity variation experiments, it was found that removal efficiency showed a positive correlation with the light intensity ranged from 0 to $80 \mu \mathrm{mol} \mathrm{m}-2 \mathrm{~s}-1$. To estimate the exchange of carbonyls between plant and atmosphere perferably, more experiments on the researches of absorption mechaism and the removal efficiency of plant under specific environments should be conducted.

\section{Acknowledgements}

This work was financially supported by the National Natural Science Foundation of China (Grants 21467018, 41003057, 41203076), the Natural Science Foundation of Jiangxi Province of China 20142BBG70005, 20151BAB203027), Foundation of Jiangxi Educational Committee (GJJ14511, GJJ14406) and Fund of Key Laboratory of Jiangxi Province for Persistent Pollutants Control and Resources Recycle (ST2013220).

\section{References}

[1] Wang, B., Lee, S.C., Ho, K.F., 2007. Characteristics of carbonyls: Concentrations and source strengths for indoor and outdoor residential microenvironments in China. Atmos. Environ. 41, 2851-2861.

[2] Orwell, R., Wood, R.L., Tarran, J., 2004. Removal of benzene by the indoor plant/ substance microcosm and implications for air quality. Water Air Soil Pollut. 157, $193-207$.

[3] Wu, X.M., Apte, M.G., Maddalena, R., Bennett, D.H., 2011. Volatile organic compounds in small-and medium-sized commercial buildings in California. Environ. Sci. Technol. 45, 90759083.

[4] Weng, M., Zhu, L., Yang, K., Chen, S., 2010. Levels, sources, and health risks of carbonyls 
inresidential indoo rair in Hangzhou, China. Environ. Monit. Assess. 163, 573-581.

[5] Duan, J., Guo, S., Tan, J., Wang, S., Chai, F., 2012. Characteristics of atmospheric carbonyls during haze days in Beijing, China. Atmos. Res. 114, 17-27.

[6] Feng, Y., Mu, C., Zhai, J., Li, J., Zou, T., Characteristics and personal exposures of carbonyl compounds in the subway stations and in-subway trains of Shanghai, China. J. Hazard. Mater. $183,574-582$.

[7] Feng, Y., Wen, S., Wang, X., Sheng, G., He, Q., Tang, J., Fu, J., 2004. Indoor and outdoor carbonyl compounds in the hotel ballrooms in Guangzhou, China. Atmos. Environ. 38, 103112.

[8] Lü, H., Cai, Q.Y., Wen, S., Chi, Y., Gu, S., Sheng, G., Fu, J., 2010. Seasonal and diurnal variations of carbonyl compounds in the urban atmosphere of Guangzhou, China. Sci. Total Environ. 408, 3523-3529.

[9] Sin, D.W.M., Wong, Y.C., Louie, P.K.K., 2001. Trends of ambient carbonyl compounds in the urban environment of Hong Kong. Atmos. Environ. 35, 5961-5969.

[10] Wang, H.K., Huang, C.H., Chen, K.S., Peng, Y.P., Lai, C.H., 2010. Measurement and source characteristics of carbonyl compounds in the atmosphere in Kaohsiung city, Taiwan. J. hazard. Mater. 179, 1115-1121.

[11] Dai, W.T., Ho, S.S.H., Ho, K.F., Liu, W.D., Cao, J.J., Lee, S.C., 2012. Seasonal and diurnal variations of mono-and di-carbonyls in Xi'an, China. Atmos. Res. 113, 102-112.

[12] Bakeas, E.B., Argyris, D.I., Siskos, P.A., 2003. Carbonyl compounds in the urban environment of Athens, Greece. Chemosphere. 52, 805-813

[13] Grosjean, D., Grosjean, E., Moreira, L.F.R., 2002. Speciated ambient carbonyls in Rio de Janeiro, Brazil. Environ. Sci. Technol. 36, 1389-1395.

[14] Fujii, S., Cha, H., Kagi, N., Miyamura, H., Kim, Y.S., 2005. Effects on air pollutant removal by plant absorption and adsorption. Build. Environ. 40, 105-112.

[15] Rottenberger, S., Kuhn, U., Wolf, A., Schebeske, G., Oliva, S.T., Tavares, T. M., Kesselmeier, J., 2004. Exchange of short-chain aldehydes between Amazonian vegetation and the atmosphere. Ecol. Appl. 14, 247-262. 